\title{
Alat Monitoring Suhu Kelembapan dan Kecepatan Angin dengan Akuisisi Database Berbasis Raspberry Pi
}

\author{
Riza Samsinar $^{1}$, Rifan Septian ${ }^{2}$, Fadliondi $^{3}$ \\ ${ }^{1,2,3}$ Jurusan Teknik Elektro, Fakultas Teknik Universitas Muhammadiyah Jakarta \\ Jl. Cempaka Putih Tengah 27, Jakarta Pusat 10510 \\ 1) riza.samsinar@ftumj.ac.id, ${ }^{2)} 2014420071 @$ ftumj.ac.id, ${ }^{3)}$ fadliondi@ftumj.ac.id
}

\begin{abstract}
ABSTRAK
Indonesia merupakan negara dengan panjang garis pantai kedua terpanjang didunia setelah Kanada. Hal tersebut dapat dimanfaatkan dengan membangun teknologi listrik terbarukan seperti pembangkit listrik tenaga angin. Namun, masih banyak ditemukan kendala dalam pelaksanaannya seperti penentuan lokasi pantai yang memiliki banyak tenaga angin untuk menggerakan turbin secara maksimal. Oleh karena itu dibutuhkan alat yang dapat memantau kecepatan angin serta kondisi disekitar pantai agar dapat dilakukan pemasangan turbin listrik bertenaga angin ditempat tersebut. Alat pembaca kecepatan angin biasa disebut sebagai Anemometer dan alat pembaca arah angin disebut Windvane, penggabungan alat tersebut dapat menjadi salah satu solusi agar dapat mengetahui lokasi pantai yang memiliki banyak angin secara tepat dan maksimal. Penambahan sensor suhu dan kelembapan akan menambah parameter kondisi lingkungan pantai untuk penelitian lebih lanjut. Hasil yang didapatkan pada perancangan alat ini adalah pembacaan kecepatan angin $(\mathrm{m} / \mathrm{s})$ arah angin serta temperatur dan humiditas $(\%)$ keadaan lokasi pantai tersebut dan datanya akan disimpan pada database yang terdapat pada Raspberry Pi dengan menggunakan Sqlite.
\end{abstract}

Kata kunci: Pantai, Anemometer, Windvane, Raspberry Pi, Database, Sqlite.

\begin{abstract}
Indonesia is a country with the second longest coastline in the world after Canada. This can be utilized by building renewable electricity technologies such as wind power plants. However, there are still many obstacles in its implementation such as determining the location of the beach that has a lot of wind power to move the turbine to the maximum. Therefore we need a tool that can monitor the speed of the wind and the conditions around the coast so that it can be installed in a windpowered electric turbine. Wind speed readers are commonly referred to as Anemometers and wind direction readers called Windvane, combining these tools can be one solution to be able to find out the location of the beach that has a lot of wind accurately and maximally. Addition of temperature and humidity sensors will add to the parameters of the coastal environment for further research. The results obtained in the design of this tool are wind speed $(\mathrm{m} / \mathrm{s})$ readings and temperature and humidity (\%) the condition of the beach location and the data will be stored in the database contained on the Raspberry Pi using Sqlite.
\end{abstract}

Keywords : Coastline, Anemometer, Windvane, Raspberry Pi, Database, Sqlite.

\section{PENDAHULUAN}

Indonesia adalah negara dengan panjang garis pantai kedua terpanjang didunia setelah Kanada dengan panjang garis pantai $54,716 \mathrm{~km}$. Melihat hal tersebut, diketahui bahwa Indonesia menyimpan potensi angin laut yang besar untuk dimanfaatkan menjadi energi. Angin sangat penting bagi manusia[1]. Angin secara umum adalah setiap gerakan udara relatif terhadap permukaan bumi [2]. Data kecepatan angin dibutuhkan untuk memperkirakan cuaca di suatu tempat [3]. Kondisi lingkungan yang ada disekitar kita dipengaruhi oleh angin [4]. Untuk dapat memanfaatkan energi angin tersebut, maka dibutuhkan alat untuk mengetahui kecepatan angin, arah angin, suhu dan kelembapan udara dipesisir pantai agar dapat dimanfaatkan secara optimal. Akuisisi data kecepatan dan arah angin dibutuhkan untuk mendapatkan data yang akan digunakan dalam berbagai sektor kehidupan [5]. Ada banyak alat yang dapat digunakan untuk mengukur kecepatan angin dan arah angin, salah satunya adalah anemometer. Dengan adanya Internet of Things dapat memudahkan pengguna saat mengakses atau menggunakan piranti yang berada pada jarak jauh [6]. Sumber energi fosil seperti minyak bumi, gas alam dan batubara akan bisa bertahan jika sumber energi terbarukan digunakan [7]. Saat ini, perkembangan dunia teknologi yang 
demikian mengagumkan itu telah membawa manfaat yang luar biasa bagi kemajuan peradaban umat manusia [8]. Material organik telah menjadi perhatian para peneliti meskipun karakternya kurang dari silicon [9]. Energi matahari dimanfaatkan sebagai sumber energi alternatif yang potensial [10]. Dalam perkembangan teknologi saat ini, listrik menjadi salah satu kebutuhan yang sangat penting bagi kehidupan masyarakat, baik dalam rumah tangga maupun dalam bidang industri [11]. Salah satu bahan semikonduktor organik yang sering digunakan adalah pentacene karena ketersediaannya dan kinerja divaisnya [12]. Pada saat ini berkembang pesat pembangunan gedung gedung pencakar langit di berbagai belahan dunia dan gedung tersebut pasti membutuhkan transportasi vertical [13]. Semakin pesatnya perkembangan dunia otomotive khususnya kendaraan roda 4 atau yang sering kita sebut mobil, mendorong para produsen kendaraan mobil ini untuk berinovasi mengembangkan teknologi pada kendaraan yang di produksi [14]. Energi sangat penting untuk manusia untuk bisa bertahan hidup [15]. Termoelektrik adalah fenomena di mana energi panas diubah menjadi listrik dan sebaliknya [16].

Namun, anemometer yang banyak dijual dipasaran kebanyakan belum bisa menampilkan trend arah dan kecepatan angin untuk nantinya disimpan dalam sebuah penyimpanan data. Data tersebut nantinya akan berguna untuk digunakan sebagai bahan penelitian penempatan alat generator pembangkit listrik tenaga angin. Selain itu, data tersebut juga dapat menjadi referensi untuk mengetahui terjadinya anomali angin di laut untuk pencegahan dini bila terjadi badai.

Untuk mengatasi hal tersebut maka penulis akan merancang sebuah alat yang dapat membaca suhu kelembapan dan kecepatan serta arah angin. Alat pengukur kecepatan angin terdiri dari tiga bagian sistem kerja yaitu input, proses, dan output. Pada bagian input terdiri dari balingbaling sebagai penangkap angin dan sensor optocoupler sebagai pengirim counter pada raspberry pi. Terdapat juga sensor suhu DHT22 yang akan menjadi input data suhu dan kelembapan. Pada bagaian proses terdapat raspberry pi sebagai pengolah data dan menyimpan data dalam bentuk format .DB dan pada bagian output data dalam format .DB akan dikonversi menjadi file .xlsx untuk bisa dibuka pada aplikasi MS.Excel. Adapun proses dalam pengambilan data dilakukan dengan cara membandingkan alat ukur angin terhadap anemometer standart menggunakan kipas angin yang mempunyai tegangan $220 \mathrm{~V}$. Kecepatan angin yang diukur memiliki kesalahan relatif terkecil $3,5 \%$ dan kesalahan relatif terbesar $5,1 \%$.
Kesalahan relatif terjadi karena terdapat faktorfaktor yang mempengaruhi seperti posisi anemometer standar dengan alat ukur angin terletak pada sudut yang berbeda sehingga data yang diperoleh tidak stabil dan mekanika balingbaling dibuat dengan alat bantu yang sederhana sehingga gaya gesekan yang terjadi tidak sebesar 0. Diharapkan alat ini dapat digunakan untuk mengukur kecepatan, arah angin, suhu dan kelembapan udara secara real time di garis pantai untuk memonitoring keadaang angin laut. Tujuan penelitian ini adalah sebagai berikut:

1. Membuat sebuah alat pengukur suhu kelembapan dan kecepatan angin menggunakan Raspberri Pi.

2. Mendapatkan data suhu kelembapan dan kecepatan angin kemudian menyimpannya dalam sebuah data logger pada database .

3. Memonitoring suhu kelembapan dan kecepatan angin yang kemudian dianalisa hasil pembacaannya pada waktu pengukuran yang berbeda.

Rumusan masalah pada penelitian ini diantaranya sebagai berikut:

1. Bagaimana cara membuat alat pengukur suhu kelembapan dan kecepatan angin agar dapat menyimpan datanya ke database?

2. Bagaimana cara kerja dari alat pengukur kecepatan angin \& sensor DHT22 menggunakan Raspberry Pi ?

3. Bagaimana proses dan cara menyimpan data suhu kelembapan \& kecepatan angin melalui database pada Raspberry Pi ?

Agar penelitian ini terfokus pada permasalahan, maka ruang lingkup penelitian ini dibatasi pada :

1. Menggunakan sensor optocoupler, sensor DHT22, Raspberry pi, LCD 3.5 Inch display, sebagai komponen utama.

2. Sensor yang digunakan adalah sensor optocoupler sebagai pembaca kecepatan angin dan DHT22 sebagai sensor suhu dan kelembapan.

3. LCD display yang digunakan adalah tipe 3.5 inch Raspberry yang sudah bisa diakses melalui raspberry melalui port GPIO.

4. Mikrokontroler yang digunakan adalah Raspberry Pi board tipe 3 versi 3 made in UK dengan OS Raspbian dan bahasa pemrograman Python 3.

5. Pengambilan data pertama dilakukan dengan kipas angin AC $220 \mathrm{~V}$ dan kemudian setelah sudah berhasil di uji coba di garis pantai.

\section{TINJAUAN PUSTAKA}


RESISTOR (Elektronika Kendali Telekomunikasi Tenaga Listrik Komputer) Vol. 3 No. 1 e-ISSN : 2621-9700, p-ISSN : 2654-2684

Radio Frequency Identification (RFID) Raspberry Pi adalah sebuah komputer papan tunggal (single-board computer) atau SBC berukuran kartu kredit. Raspberry Pi telah dilengkapi dengan semua fungsi layaknya sebuah komputer lengkap, menggunakan SoC (System-on-a-chip) ARM yang dikemas dan diintegrasikan diatas PCB. Raspberry $\mathrm{Pi}$ adalah sebuah komputer yang menjalankan sistem Linux [17]. Perangkat ini menggunakan kartu SD untuk booting dan penyimpanan jangka panjang [18].



Gambar 1 Logo Raspberry Pi [19].

Raspberry Pi memiliki dua model yaitu model A dan model B. Secara umum Raspberry Pi Model B, 512MB RAM. Perbedaan model A dan B terletak pada memory yang digunakan, Model A menggunakan memory $256 \mathrm{MB}$ dan model B 512 MB. Selain itu model B juga sudah dilengkapai dengan ethernet port (kartu jaringan) yang tidak terdapat di model A. Desain Raspberry Pi didasarkan seputar SoC (System-on-a-chip) Broadcom BCM2835, yang telah menanamkan prosesor ARM1176JZF-S dengan $700 \mathrm{MHz}$, VideoCore IV GPU, dan 256 Megabyte RAM (model B). Penyimpanan data didisain tidak untuk menggunakan hard disk atau solid-state drive, melainkan mengandalkan kartu SD (SD memory card) untuk booting dan penyimpanan jangka panjang. Hardware Raspberry Pi tidak memiliki realtime clock, sehingga OS harus memanfaatkan timer jaringan server sebagai pengganti. Namun komputer yang mudah dikembangkan ini dapat ditambahkan dengan fungsi real-time (seperti DS1307) dan banyak lainnya, melalui saluran GPIO (Generalpurpose input/output) via antarmuka $\mathrm{I}^{2} \mathrm{C}$ (InterIntegrated Circuit). Raspberry $\mathrm{Pi}$ bersifat open source (berbasis Linux), Raspberry Pi bisa dimodifikasi sesuai kebutuhan penggunanya. Sistem operasi utama Raspberry Pi menggunakan Debian GNU/Linux dan bahasa pemrograman Python. Ada dua cara untuk memakai Phyton yakni memakai phyton interpreter prompt atau mengeksekusi file phyton dari command file [20]. Salah satu pengembang OS untuk Raspberry $\mathrm{Pi}$ telah meluncurkan sistem operasi yang dinamai Raspbian,
Raspbian diklaim mampu memaksimalkan perangkat Raspberry Pi. Sistem operasi tersebut dibuat berbasis Debian yang merupakan salah satu distribusi Linux OS.

Anemometer adalah alat ukur yang digunakan untuk mengukur atau menentukan kecepatan angin. Anemometer merupakan salah satu instrument yang sering digunakan oleh Badan Meterologi Klimatologi dan Geofisika (BMKG). Kata anemometer berasal dari Bahasa Yunani anemos yang berarti angin, angin merupakan udara yang bergerak ke segala arah, angin bergerak dari suatu tempat menuju ke tempat yang lain. Anemometer ini pertama kali diperkenalkan oleh Leon Batista Alberti dari italia pada tahun 1450. Anemometer harus ditempatkan di daerah terbuka. Pada saat tertiup angin, mangkok yang terdapat pada anemometer akan bergerak sesuai arah angin. Makin besar kecepatan angin meniup mangkok tersebut, makin cepat pula kecepatan berputarnya piringan mangkok tersebut, makin cepat pula kecepatan berputarnya piringan mangkok. Dari jumlah putaran dalam satu detik maka dapat diketahui kecepatan anginnya. Didalam anemometer terdapat alat pencacah yang akan menghitung kecepatan angin.

Jenis anemometer yang biasa digunakan adalah anemometer mangkok dan baling-baling. Anemometer cup paling umum dan sering digunakan dikarenakan cara pembuatan yang mudah dan sederhana. Anemometer merupakan sensor angin untuk mengukur kecepatan angin di sekitarnya dan juga banyak digunakan pada stasiun pengukuran cuaca. Pengukuran kecepatan/RPM angin yang bisa digunakan ada beberapa metode yang digunakan, salah satunya menghitung waktu yang terjadi tiap munculnya sinyal pulsa, namun perhitungan yang diterapkan pada percobaan ini didasarkan atas konsep rotasi per menit, yakni menghitung jumlah rotasi yang dilakukan peralatan salam satu menit, jumlah rotasi tersebut dapat diketahui dengan menghitung jumlah pulsa yang dibangkitkan oleh sensor. Agar di dapatkannya waktu pembacaan yang lebih cepat maka dapat dilakukan pengukuran dalam waktu singkat namun di kompensasi dengan faktor pengali. Angin yang menerpa cup anemometer akan menggerakkan cup [21]. 


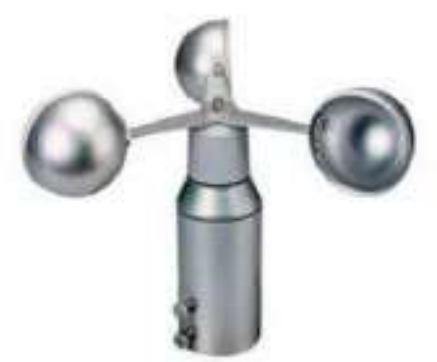

Gambar 2 Sensor anemometer untuk mengukur kecepatan angin [22].

Wind vane berupa sirip yang digunakan sebagai acuan dari mana arah angin datang. Pengukuran arah angin digunakan berupa sirip yang memiliki bentuk yang tidak simeteris [23]. Arah angin dibuat dari dua bagian pada bagian A mendapatkan tekanan angin lebih besar dari pada bagian $\mathrm{B}$, karena bagian A memiliki penampang yang lebih besar dari bagian B [23]. Wind vane berupa sirip yang digunakan sebagai acuan dari mana arah angin datang. Pengukuran arah angin digunakan berupa sirip yang memiliki bentuk yang tidak simeteris [23]. Arah angin dibuat dari dua bagian pada bagian A mendapatkan tekanan angin lebih besar dari pada bagian B, karena bagian A memiliki penampang yang lebih besar dari bagian $\mathrm{B}$ [23].

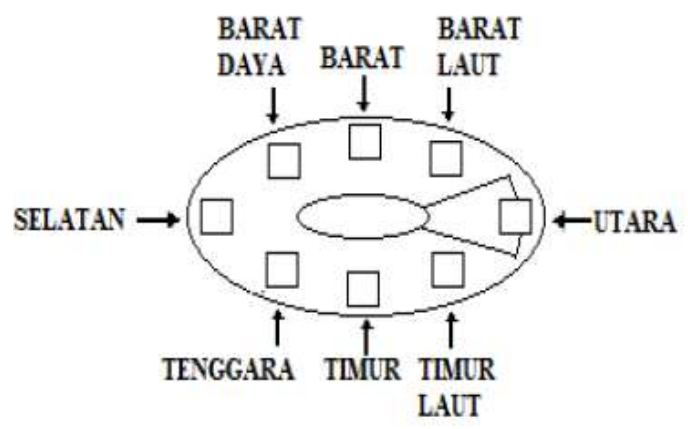

Gambar 3 Tata letak sensor pembaca arah angin

[21].

DHT22 merupakan sensor dengan kalibrasi yang menerapkan teknik pengumpulan sinyal digital dan teknologi pengindraan kelembaban. Sensor ini memiliki keandalan dan stabilitas sangat baik. Elemen pengindraan sensor ini terhubung dengan 8 bit chip tunggal komputer. DHT22 memiliki fitur kalibrasi dan koefisien yang sangat akurat. Koefisien kalibrasi ini disimpan pada program dalam memori OTP program memori, sehingga ketika internal sensor mendeteksi sesuatu, maka modul ini membaca sensor tersebut.

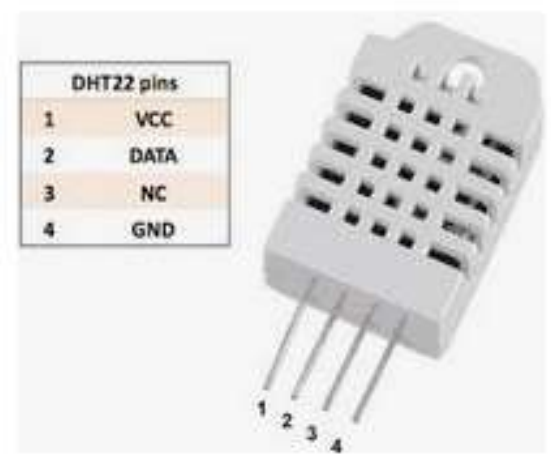

Gambar 4 Sensor DHT22 [24].

Pada penelitian ini, penulis akan membuat sebuah alat yang dapat memonitoring suhu kelembapan dan kecepatan angin di pantai untuk mengetahui kondisi lingkungan pada pantai tertentu untuk dijadikan data acuan penempatan pembangkit listrik tenaga angin.

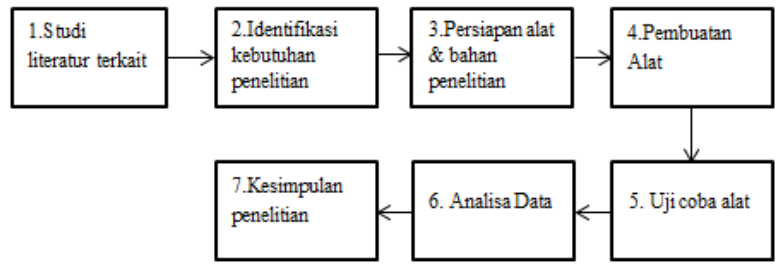

Gambar 5 Diagram prosedur penelitan.

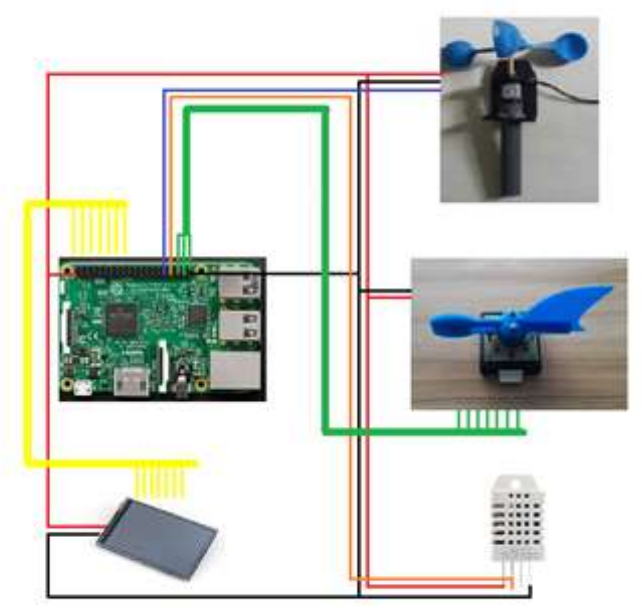

Gambar 6 Blok diagram system.

Keterangan gambar 2: 
RESISTOR (Elektronika Kendali Telekomunikasi Tenaga Listrik Komputer) Vol. 3 No. 1 e-ISSN : 2621-9700, p-ISSN : 2654-2684

1. Mikrokontroler raspberry pi

2. Sensor Anemometer

3. Sensor Windvane

4. Sensor DHT22

5. LCD Display 3.5 Inch

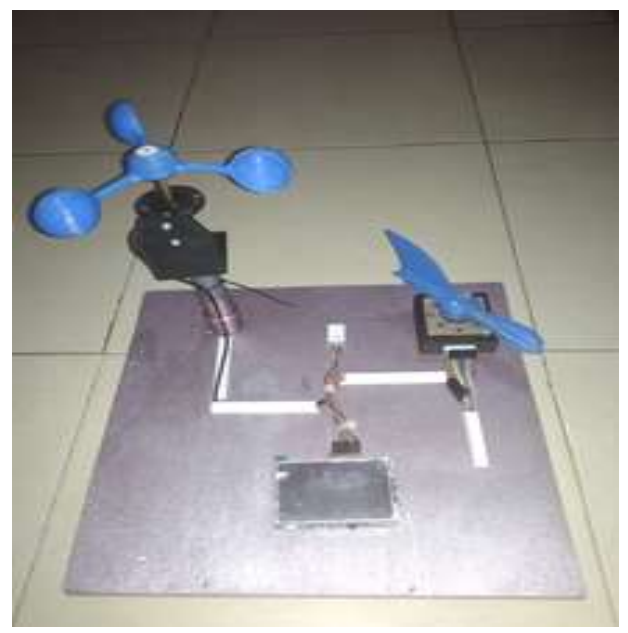

Gambar 7 Sistem tampak depan.

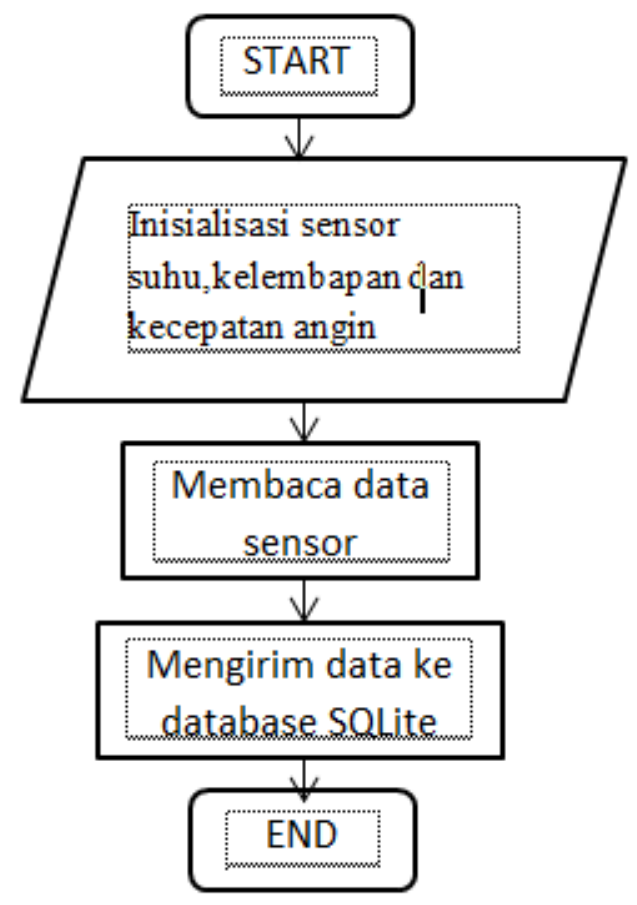

Gambar 8 Flow chart sistem.

Sistem monitoring kecepatan angin, arah angin, dan suhu kelembapan ini terdari dari 3 bagian sensor pembacaan yaitu :

1. Sensor kecepatan angin(anemometer)

Pada bagian ini, sensor anemometer yang terdiri dari desain cup anemometer serta sensor optocoupler akan membaca kecepata angin berdasarkan kecepatan putaran cup anemometer per satuan waktu. Ketika cup anemometer berputar maka sensor coptocoupler akan membaca data kecepatan putaran tersebut yang nantinya akan dihitung kecepatannya persatuan waktu oleh Raspberry pi. Hasil keluarannya berupa data kecepatan angin dalam satuan $(\mathrm{m} / \mathrm{s})$.

2. Sensor arah angin(windvane)

Pada bagian ini, sensor arah angin akan membaca data digital dari sirip sensor yang akan menerima tekanan udara atau angin. Penunjuk sirip akan bergerak sesuai dengan arah angin yang mengenainya, sehingga sensor windvane akan membaca data digital posisi sirip sensor dan memberikan data tersebut kepada Raspberry untuk mengetahui posisi arah angin tersebut datang.

\section{Sensor DHT22}

Sensor DHT22 berfungsi untuk mendapatkan data suhu dan kelembapan didaerah pantai untuk mengetahui kondisi lingkungan yang ada didaerah tersebut guna data penelitian lebih lanjut. Data tersebut akan dikirim ke Raspberry pi untuk kemudian disimpan dalam sebuah penyimpanan akuisisi database menggunakan Sqlite agar data tersebut dapat dianalisa lebih lanjut oleh pengguna untuk mengetahui lokasi yang tepat sebagai penempatan pembangkit listrik tenaga angin di pantai.

\section{PENGUJIAN DAN HASIL}

Pengujian Snesor DHT22 bertujuan untuk mendapatkan data suhu dan kelembapan didaerah tertentu untuk penelitian lebih lanjut.

Tabel 1 Hasil pengukuran suhu dan kelembapan.

\begin{tabular}{|c|c|l|l|l|}
\hline No & $\begin{array}{c}\text { Temperatur } \\
\text { sensor } \\
\text { DHT22 } \\
\text { (Celcius) }\end{array}$ & $\begin{array}{c}\text { Kelembapan sensor } \\
\text { DHT22 } \\
(\%)\end{array}$ & $\begin{array}{c}\text { Temperatur } \\
\text { Thermometer } \\
\text { Digital } \\
\text { (Celcius) }\end{array}$ & $\begin{array}{c}\text { Kelembapan } \\
\text { Thermometer } \\
\text { Digital } \\
\text { (\%) }\end{array}$ \\
\hline 1 & 26.3 & 75 & 26.3 & 74.8 \\
\hline 2 & 26.5 & 75.1 & 26.4 & 75 \\
\hline 3 & 27.4 & 77.5 & 27.5 & 77.5 \\
\hline 4 & 28.1 & 74.3 & 28 & 74.2 \\
\hline 5 & 29.3 & 73.5 & 29.3 & 73.5 \\
\hline 6 & 29.5 & 73.3 & 29.4 & 73.4 \\
\hline 7 & 29.8 & 73.2 & 29.8 & 73.2 \\
\hline 8 & 30.1 & 72.5 & 30.1 & 72.6 \\
\hline 9 & 30.5 & 72.1 & 30.6 & 72 \\
\hline 10 & 31 & 71.7 & 30.9 & 71.8 \\
\hline 11 & 31.2 & 71.5 & 31.3 & 71.5 \\
\hline 12 & 31.5 & 71.2 & 31.5 & 71.2 \\
\hline 13 & 31.7 & 71 & 31.8 & 71.1 \\
\hline
\end{tabular}


RESISTOR (Elektronika Kendali Telekomunikasi Tenaga Listrik Komputer) Vol. 3 No. 1 e-ISSN : 2621-9700, p-ISSN : 2654-2684

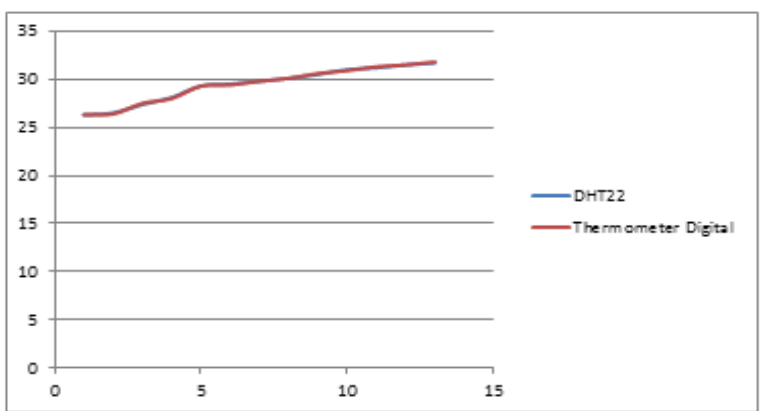

Gambar 9 Grafik pengujian pembacaan suhu.

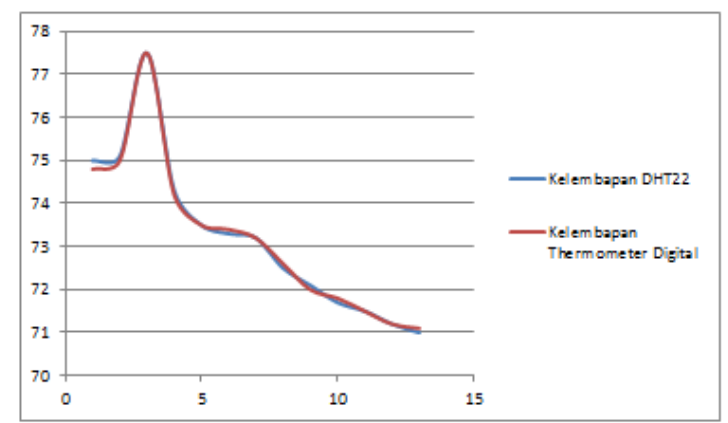

Gambar 10 Grafik pengujian pembacaan kelembapan.

Pengujian Sensor Kecepatan angin ini dilakukan untuk mengetahui seberapa akurat pembacaan sensor yang dibuat dibandingkan dengan sensor digital yang sudah banyak dijual dipasaran untuk mengetahui nilai kesalahan atau toleransi pembacaan sensor yang dimiliki oleh alat yang penulis buat.
Tabel 2 Hasil pengujian sensor kecepatan angin.

\begin{tabular}{|l|c|l|}
\hline No & $\begin{array}{c}\text { Sensor Kecepatan } \\
\text { Angin }(\mathrm{m} / \mathrm{s})\end{array}$ & $\begin{array}{c}\text { Pembacaan } \\
\text { Anemometer }(\mathrm{m} / \mathrm{s})\end{array}$ \\
\hline 1 & 1.2 & 1.3 \\
\hline 2 & 1.4 & 1.4 \\
\hline 3 & 1.7 & 1.7 \\
\hline 4 & 1.9 & 2.0 \\
\hline 5 & 2.2 & 2.2 \\
\hline 6 & 2.4 & 2.5 \\
\hline 7 & 2.6 & 2.6 \\
\hline 8 & 2.8 & 2.8 \\
\hline 9 & 2.9 & 2.9 \\
\hline 10 & 3.1 & 3.0 \\
\hline 11 & 3.2 & 3.2 \\
\hline 12 & 3.3 & 3.3 \\
\hline 13 & 3.5 & 3.5 \\
\hline
\end{tabular}

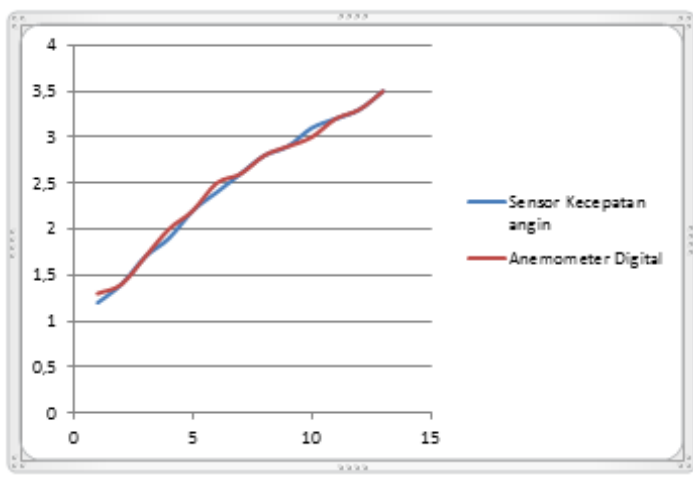

Gambar 11 Grafik pengujian pembacaan sensor kecepatan angin.

Pengujian Sensor arah angin(windvane) ini bertujuan untuk mengetahui posisi arah angin yang datang melalui pantai sehingga data tersebut berguna untuk mengetahui posisi dimana angin sering datang sebagai acuan penempatan pembangkit listrik tenaga angin. 
RESISTOR (Elektronika Kendali Telekomunikasi Tenaga Listrik Komputer) Vol. 3 No. 1 e-ISSN : 2621-9700, p-ISSN : 2654-2684

Tabel 3 Hasil pengujian sensor arah angin

\begin{tabular}{|l|c|l|}
\hline No & Windvane Sensor & \multicolumn{1}{|c|}{$\begin{array}{c}\text { Pembacaan Arah } \\
\text { Angin }\end{array}$} \\
\hline 1 & Utara & Utara \\
\hline 2 & Timur Laut & Timur Laut \\
\hline 3 & Timur & Timur \\
\hline 4 & Tenggara & Tenggara \\
\hline 5 & Selatan & Selatan \\
\hline 6 & Barat Daya & Barat Daya \\
\hline 7 & Barat & Barat \\
\hline 8 & Barat Laut & Barat Laut \\
\hline
\end{tabular}

Pengujian alat dilakukan dilokasi pantai Ancol Jakarta guna mendapatkan hasil data yang sesuai dengan keadaan nyata dilapangan. Sebagai perbandingan data dengan pengujian serta analisa data untuk mengetahui kondisi tertentu didaerah pantai Ancol Jakarta. Pengujian dan pengambilan data dilakukan tanggal 21 Oktober 2018 dari pukul 13.00 hingga pukul 18.00 .

Tabel 4 Pengujian alat di pantai Ancol Jakarta.

\begin{tabular}{|l|c|c|c|c|}
\hline Waktu & $\begin{array}{c}\text { Temperatur } \\
\text { sensor } \\
\text { DHT22 } \\
\text { (Celcius) }\end{array}$ & $\begin{array}{c}\text { Kelembapan sensor } \\
\text { DHT22 } \\
(\%)\end{array}$ & $\begin{array}{c}\text { Sensor } \\
\text { Kecepatan } \\
\text { Angin } \\
(\mathbf{m} / \mathbf{s})\end{array}$ & $\begin{array}{c}\text { Sensor Arah } \\
\text { Angin }\end{array}$ \\
\hline 13.00 & 27.5 & 75.5 & 2.3 & Timur Laut \\
\hline 13.20 & 28.3 & 75.7 & 2.1 & Timur Laut \\
\hline 13.40 & 28.5 & 77.5 & 2.0 & Timur Laut \\
\hline 14.00 & 28.7 & 76.3 & 1.7 & Timur Laut \\
\hline 14.20 & 29.1 & 76.1 & 2.0 & Timur Laut \\
\hline 14.40 & 29.5 & 76.0 & 2.5 & Timur Laut \\
\hline 15.00 & 28.5 & 77.3 & 3.0 & Timur Laut \\
\hline 15.20 & 28.3 & 77.5 & 3.2 & Timur Laut \\
\hline 15.40 & 27.8 & 77.4 & 3.3 & Tenggara \\
\hline 16.00 & 27.6 & 78.1 & 2.9 & Tenggara \\
\hline 16.20 & 27.5 & 77.7 & 2.7 & Tenggara \\
\hline 16.40 & 27.2 & 78.8 & 2.5 & Timur \\
\hline 17.00 & 26.7 & 80.2 & 2.1 & Timur \\
\hline 17.20 & 26.5 & 81.1 & 2.6 & Timur Laut \\
\hline 17.40 & 26.3 & 80.3 & 2.1 & Timur \\
\hline 18.00 & 25.7 & 81.2 & 2.0 & Timur \\
\hline & & & & \\
\hline
\end{tabular}

\section{KESIMPULAN}

Berdasarkan hasil pengujian yang telah dilakukan, maka dapat disimpulkan beberapa hal sebagai berikut:

1. Pada pengujian sensor suhu dan kelembapan, suhu yang terbaca di lokasi Pantai Ancol antara pukul 13.00 sampai 18.00 adalah berkisar 25.7 derajat hingga 29.5 derajat celcius.

2. Pada pengujian sensor kecepatan angin yang terbaca di lokasi Pantai Ancol antara pukul 13.00 sampai 18.00 adalah berkisar $1.7 \mathrm{~m} / \mathrm{s}$ hingga $3.3 \mathrm{~m} / \mathrm{s}$

3. Pada pengujian sensor arah angin yang terbaca di lokasi Pantai Ancol antara pukul 13.00 sampai 18.00 adalah Timur Laut Hingga Tenggara

4. Alat berfungsi normal dan dapat memonitoring suhu kelembapan, kecepatan angin dan arah angin dengan baik dan dapat dijadikan data acuan untuk kedepannya bila ada penelitian memasang generator pembangkit listrik tenaga angin di pantai.

\section{DAFTAR PUSTAKA}

[1] H. Sibarani, "Herbert Sibarani. 2010. 'Rancangan Bangun Pendeteksi Kecepatan Angin Dengan Teknik Generator DC B erbasis Mikrokontroller AT 89S51'. Universitas Indonesia.," Universitas Indonesia, 2010.

[2] R. Banodin, A. Fatchur Rochim, and T. Andromeda, "Alat Penunjuk Arah Angin dan Pengukur Kecepatan Angin Berbasis Mikrokontroller AT89C51," Jurusan Teknik Elektro Fakultas Teknik Undip, 2011.

[3] A. ari As' ari, "RANCANG BANGUN ANEMOMETER ANALOG," JURNAL ILMIAH SAINS, vol. 11, no. 1, pp. 19-22, 2011.

[4] S. Jumini and L. Holifah, "Menentukan Kondisi Lingkungan Berdasarkan Pengukuran Kecepatan Angin Dengan Anemometer Sederhana," Jurnal Penelitian dan Pengabdian Kepada Masyarakat UNSIQ, vol. 1, no. 2, pp. 144-148, 2014.

[5] A. R. Hakim, "Alat Ukur Kecepatan Dan Arah Angin Berbasis Komputer," Jurnal Teknik Elektro, vol. 1, no. 1, 2009.

[6] H. Isyanto and A. Nandiwardhana, "Perancangan DC Cooler Berbasis Internet of Things," RESISTOR (elektRonika kEndali telekomunikaSI tenaga liSTrik kOmputeR), vol 2, no. 2, pp. 95-104, 2019.

[7] F. Fadliondi, H. Isyanto, and B. Budiyanto, "Bypass Diodes for Improving Solar Panel Performance," International Journal of 
RESISTOR (Elektronika Kendali Telekomunikasi Tenaga Listrik Komputer) Vol. 3 No. 1 e-ISSN : 2621-9700, p-ISSN : 2654-2684

Electrical and Computer Engineering, vol. 8, no. 5, p. 2703, 2018.

[8] H. Muchtar and F. Said, "Sistem Identifikasi Plat Nomor Kendaraan Menggunakan Metode Robert Filter dan Framing Image Berbasis Pengolahan Citra Digital," RESISTOR (elektRonika kEndali telekomunikaSI tenaga liSTrik kOmputeR), vol. 2, no. 2, pp. 105-112, 2019.

[9] F. Fadliondi, H. Isyanto, and P. G. Chamdareno, "The comparison of organic field effect transistor (OFET) structures," in 2017 2nd International Conference on Frontiers of Sensors Technologies (ICFST), 2017, pp. 6-9.

[10] D. Almanda and B. P. Piliang, "Perbandingan Sistem Pendingin pada Konsentrasi Water Coolant, Air Mineral, dan Air Laut Menggunakan Panel Surya Fleksibel Monocrystaline 20 Wp," RESISTOR (elektRonika kEndali telekomunikaSI tenaga liSTrik kOmputeR), vol. 2, no. 2, pp. 73-82, 2019.

[11] E. Dermawan, P. G. Chamdareno, and A. R. Priyono, "Studi Analisa Start-Up Gas Turbin Memanfaatkan Generator Utama sebagai Motor Penggerak Mula dengan Menggunakan Static Frequency Converter (Sfc) pada Unit Blok 1-2 PT. PJB Unit Pembangkitan Muara Tawar," RESISTOR (elektRonika kEndali telekomunikaSI tenaga liSTrik kOmputeR), vol. 2, no. 2, pp. 83-88, 2019.

[12] F. Fadliondi, M. Kunta Biddinika, and S. I. Omi, "The Humidity Dependence of Pentacene Organic Metal-OxideSemiconductor Field-Effect Transistor.," Telkomnika, vol. 15, no. 2, 2017.

[13] P. G. Chamdareno, E. Dermawan, and H. Octafriandi, "Desain dan Analisa Permanen Magnet Motor Sinkron untuk Aplikasi pada Lift," RESISTOR (elektRonika kEndali telekomunikaSI tenaga liSTrik kOmputeR), vol. 2, no. 2, pp. 113-120, 2019.

[14] S. Bahri and P. S. Yuza, "Analisa Kerusakan (Deformasi) Engine Mounting Kendaraan Toyota Agya Berdasarkan Tingkat Vibrasi Berbasis Mem Accelerometer," RESISTOR (elektRonika kEndali telekomunikaSI tenaga liSTrik kOmputeR), vol. 2, no. 2, pp. 131-136, 2019.
[15] B. Budiyanto and F. Fadliondi, "The Improvement of Solar Cell Output Power Using Cooling and Reflection from Mirror," International Journal of Power Electronics and Drive Systems, vol. 8, no. 3, p. 1320, 2017.

[16] F. Fadliondi, B. Budiyanto, H. Isyanto, and P. G. Chamdareno, "Effects of Several Parameters on Thermoelectricity," vol. 62, no. 02, p. 6, 2020.

[17] S. Monk, Programming the Raspberry Pi: getting started with Python. Mcgraw-hill, 2013.

[18] B. Yuwono, S. P. Nugroho, and H. Heriyanto, "Pengembangan model public monitoring system menggunakan Raspberry pi," Telematika: Jurnal Informatika dan Teknologi Informasi, vol. 12, no. 2, pp. 123-133, 2015.

[19] "raspberrypi."

[20] R. F. Septian, "Belajar Pemograman Python Dasar," Bandung: POSS-UPI, 2013.

[21] E. Safrianti and H. Surya, "Perancangan Alat Ukur Kecepatan dan Arah Angin," Jurnal Rekayasa Elektrika, vol. 9, no. 1, pp. 30-35, 2010.

[22] "anemometer."

[23] R. A. Pesma and I. Taufiq, "Rancang Bangun Alat Ukur Kelajuan Dan Arah Angin Berbasis Mikrokontroler Atmega8535 Menggunakan Sistem Sensor Cahaya," Jurnal Fisika Unand, vol. 2, no. 4, 2013.

[24] "Humidity-sensor-DHT-22." [Online]. Available:

https://www.researchgate.net/figure/Humiditysensor-DHT-22_fig6_319316898. 